\title{
Indigenous Children's Right to Learn Their Mother Tongue at School: Implementation and Realization in Russia
}

\author{
Ekaterina Andreyevna Zmyvalova * \\ Project Assistant, Centre for Sami Studies, UiT - The Arctic University of Norway, \\ Tromsø, Norway
}

\begin{abstract}
According to official statistics, there are decreasing numbers of Nenets people - the largest group of indigenous small-numbered people in Russia - who know their native language. Moreover, it is mostly elderly people who know the language. Even though children learn the Nenets language at school, they do not know it properly. This is especially true in the Nenets Autonomous Okrug in northwest Russia. In the eight-year period between the population censuses of 2002 and 2010, the number of Nenets speakers in this area decreased threefold. While many factors have contributed to this decline, this article focuses on the legal issues that have impacted the situation. Particular emphasis is given to the inadequate implementation into national legislation of international commitments that guarantee the right of indigenous children to learn their mother tongue at school and the ineffective realization of legal commitments of national legislation concerning this right. This article examines how sources of law concerning indigenous children's right to learn their mother tongue are implemented and realized in Russia. The focus is on the Nenets Autonomous Okrug.
\end{abstract}

Keywords: indigenous children's rights; language; Nenets; education; school; implementation; realization

Responsible Editor: Øyvind Ravna, UiT - The Arctic University of Norway, Tromsø, Norway. Received: June 2015; Accepted: July 2015; Published: November 2015

\section{Introduction}

The right of indigenous children to learn their mother tongue ${ }^{1}$ is an indispensable feature of a State governed by law. All indigenous children are guaranteed this right by international law. However, in the 2014 Concluding Observations on the Implementation of the Convention on the Rights of the Child (CRC) by the Russian Federation (RF), the CRC Committee pointed out that "the native languages of some indigenous groups are never used as a language of tuition."2

According to the 2010 census, ${ }^{3}$ the percentage of the Nenets people ${ }^{4}$ capable of speaking the Nenets language in the Nenets Autonomous Okrug (NAO), ${ }^{5}$ decreased

^Correspondence to: Ekaterina Andreyevna Zmyvalova, Tunvegen 10, 9018 Tromsø, Norway. Email: ezm000@uit.post.no 


\section{E. A. Zmyvalova}

threefold compared to the data in the 2002 census. ${ }^{6}$ To compare, during the same period, in the Yamalo-Nenets Autonomous Okrug (YNAO) the number of Nenets speakers fell by one-third. This information is presented in Table 1 .

While state officials such as the vice-president of the Ministry of Culture and Education of the RF and the ombudsman for children in the NAO have declared numerous times that it is necessary to safeguard indigenous languages, ${ }^{7}$ in practice, the Russian language is prioritized in all spheres of social life. This is demonstrated by the fact that today all school exams can only be taken in Russian.

Attempts to analyze and explain the situation have been undertaken by Russian legal scholars. Kryazhkov, for example, points out that " $[t]$ here is an ignorance ... of the basics of 'indigenous legislation' in Russia." "Kharyuchi emphasizes that "[a]s a result of the changes in the legislation in recent years, indigenous small-numbered peoples of the North, Siberia and the Far East of the Russian Federation ... have lost the financial basis for the preservation and the development of their unique cultures."

The Norwegian media has also discussed the negative impact controversial legislation has had on the situation of indigenous languages in Russia. NRK Sápmi and the Barents Observer drew attention to the fact that in 2013 " $[\mathrm{t}]$ he controversial law on education, signed by President Vladimir Putin on New Year's Eve, states that classes in non-Russian languages cannot be conducted to the detriment of teaching in the Russian language." 10

Both legal scholars and the media emphasize that, among others, one of the main causes of problems related to the status and development of indigenous languages in Russia lies within the legal sphere. In this article, the focus is on legal issues and encompasses both international and national legal systems. In this regard the question of the implementation and realization of the right of indigenous children to learn their mother tongue at school is addressed.

Implementation is a formal process that ensures the compatibility of provisions of international law and national legislation. According to the 2003 General Comment No. 5 (2003) of the CRC Committee, ${ }^{11}$ implementation is the process whereby State Parties take action to ensure the realization of all rights provided in the CRC. Furthermore, implementation implies that all domestic national legislation is fully compatible with the convention's principles and provisions and that the latter can be directly applied and appropriately enforced. It is this latter understanding of

Table 1. The Nenets language in NAO and YNAO according to the 2002 and 2010 censuses.

\begin{tabular}{|c|c|c|c|c|c|c|}
\hline & \multicolumn{3}{|c|}{2002} & \multicolumn{3}{|c|}{2010} \\
\hline & $\begin{array}{c}\text { Number of } \\
\text { Nenets native } \\
\text { speakers }\end{array}$ & $\begin{array}{c}\text { Nenets } \\
\text { population }\end{array}$ & $\begin{array}{l}\text { Nenets native } \\
\text { speakers as } \\
\text { percentage of } \\
\text { population }\end{array}$ & $\begin{array}{c}\text { Number of } \\
\text { Nenets native } \\
\text { speakers }\end{array}$ & $\begin{array}{c}\text { Nenets } \\
\text { population }\end{array}$ & $\begin{array}{l}\text { Nenets native } \\
\text { speakers as } \\
\text { percentage of } \\
\text { population }\end{array}$ \\
\hline NAO & 2509 & 7752 & 32 & 778 & 7504 & 10 \\
\hline YNAO & 22,601 & 28,435 & 85 & 17,561 & 29,772 & 59 \\
\hline
\end{tabular}


implementation that is the focus of this text, while the formal procedure of implementation falls beyond the scope of the present article. Therefore, this article will examine the steps Russia has undertaken to comply with commitments it took upon itself under implemented norms. This understanding goes hand in hand with the definition of implementation provided by the UN about UN treaty bodies "that monitor implementation of the core international human right treaties." 12 By focusing on appropriate implementation, these monitoring bodies have to examine which steps States take "to ensure that everyone in the State can enjoy the rights set out in the treaty." 13

Realization, in the context of this article, refers to how legal provisions work in reality. The distinction between implementation and realization lies in whether a State has accepted or rejected the effects of a legal provision and how the legal provision impacts reality. Using this definition of realization in the context of this research, realization is best measured at the school level, where the concrete effects of legal provisions are most obvious in the everyday experience of real people.

The objective of this article is to examine how the sources of law concerning indigenous children's right to learn their mother tongue at school are implemented and realized in Russia. First, the meaning of this right will be analyzed based on sources of international law. Second, the extent to which the implementation and realization measures correspond to the requirements for appropriate implementation and effective realization of indigenous children's right to learn their native language at school will be examined. Third, where there are discrepancies and gaps in these processes, the reasons will be explored.

It is necessary to refer to the sources of international law that contain the elements of the right of indigenous children to learn their mother tongue at school. It is also necessary to analyze the sources of the Russian law in order to examine whether they contain these elements as well. In order to understand how the right is realized in practice, interviews were conducted at two schools in NAO where Nenets children learn their native language.

\section{The Nenets people and the school system}

In terms of population, the Nenets people are the largest of the indigenous smallnumbered peoples of Russia. Traditionally, the Nenets are reindeer-herding people who also support themselves by fishing and trapping.

The Nenets language belongs to the Samoyedic language group. ${ }^{14}$ The vocabulary of the Nenets language is characterized by terminology that describes their varied livelihoods: reindeer herding, fishing, and hunting.

While the Nenets people have settled across a large territory, the focus of this article lies on the territory of the NAO, constituting part of the Arkhangelsk Oblast. ${ }^{15}$ Figure 1 illustrates the location of the NAO on a map of Russia.

The NAO was founded in 1929 and became the first national okrug ${ }^{16}$ in the Russian North. ${ }^{17}$ In 1977 the okrug was renamed the NAO. According to the 2010 census, the NAO numbers $42,090^{18}$ inhabitants, and among them 7504 indentify themselves as Nenets. 


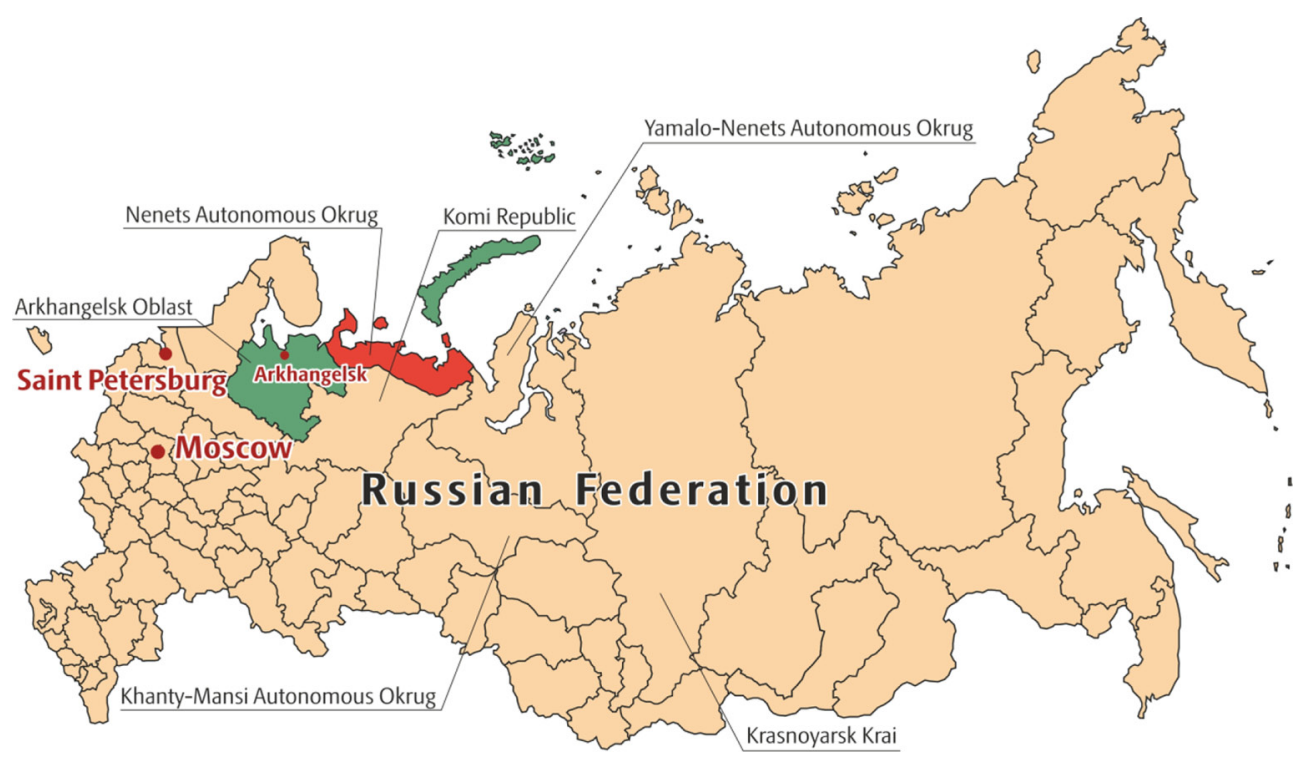

Figure 1. The Nenets Autonomous Okrug on a map of Russia (Map: (C) Aleksei Larionov).

According to the 2014 report of the NAO administration, "Annual Report on the Realization of State Policy in the Sphere of Education in the Nenets Autonomous Okrug," 19 there are 14 schools in the okrug where the Nenets language is taught. Interviews were conducted at two of these schools, in the villages of Indiga and Krasnoye, as demonstrated in Figure 2.

Indiga is the administrative center of the Timan Local Council in the NAO. The village is located $170 \mathrm{~km}$ from the administrative center of the NAO, the city of Naryan-Mar. There are two settlements in the Timan Local Council municipality: Indiga and Vuiucheiskii. According to data submitted by the council in the summer of 2014, 746 people live in Indiga and 223 in Vuiucheiskii. Children from Vuiucheiskii stay in housing provided by the school because they live too far to travel each day. However, officially the school is not a boarding school. At the school tuition is carried out in Russian and the subject "Native (non-Russian) language and literature" is taught for two hours per week.

Krasnoye is the administrative center of the Primor-Kui Local Council in the NAO. The municipality includes several settlements, including Krasnoye (the administrative center of the municipality), Kuya, Oskolkovo, and Chernaya. Krasnoye has a population of 1815 people (according to the data from 01.01 .2008 ) $^{20}$ and is located $40 \mathrm{~km}$ from the town of Naryan-Mar. In Krasnoye, school tuition is carried out in Russian and "Native (non-Russian) language and literature" is not included in the curriculum. However, according to information submitted by the Krasnoye school administration and in accordance with the educational program of "National culture", the Nenets language is taught one hour per week within this subject from fifth to ninth grade. From first to fourth grade, children may take a non-obligatory Nenets language class for one hour per week. Thus, even though the Nenets language is not a 


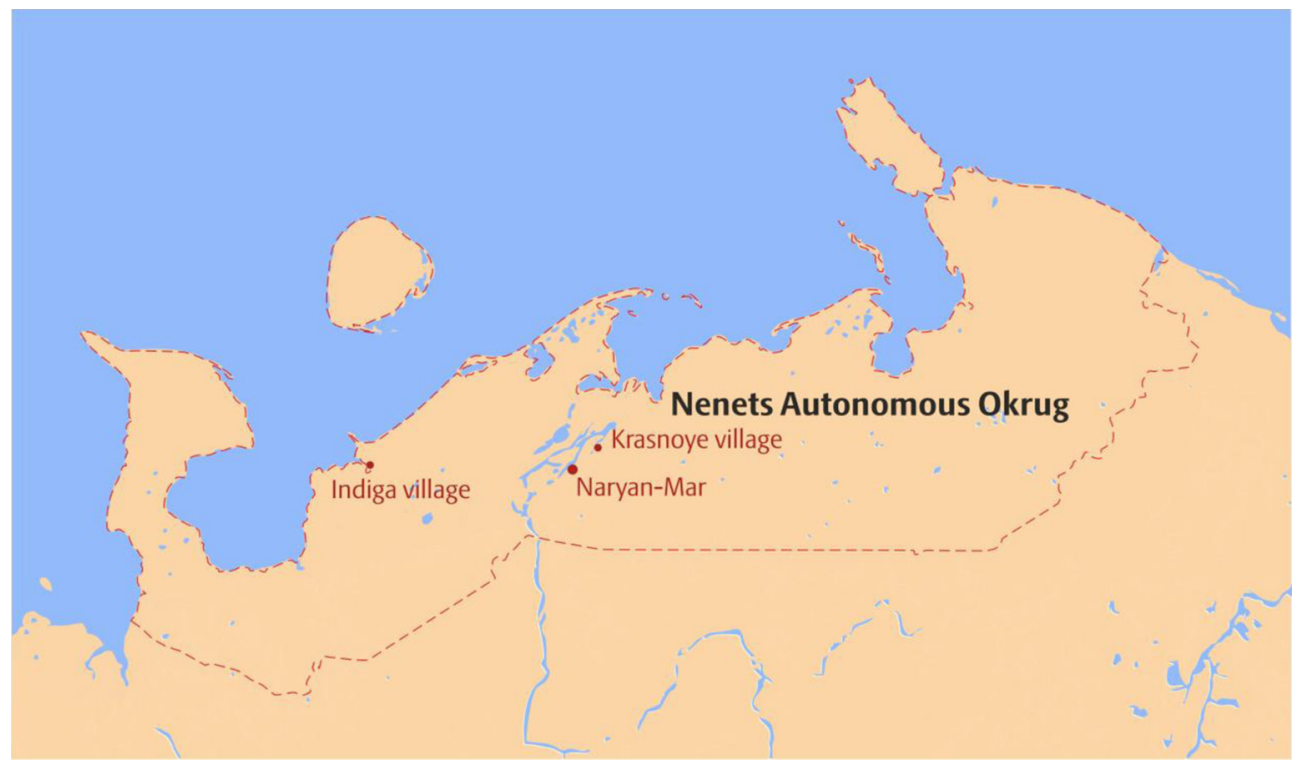

Figure 2. Indiga and Krasnoye on the map of NAO (Map: (C) Aleksei Larionov).

separate school subject, children in Krasnoye have the opportunity to learn the Nenets language.

This article covers the first two of three stages of the Russian educational system: primary general and basic general education. The third stage, secondary general education, is not the focus of current research due to the fact that some pupils enrolled in secondary school are over 18 and no longer fit the legal definition of a child given by Article 1 of the CRC. According to Article 67 (1) of FL of 29.12.2012 No. 273-FL, "On Education in the Russian Federation"21 (FL "On Education"), children should normally start school at the age of 6.5 if they have no health prohibitions, but not later than the age of 8 . Thus, the age group that is the focus of the research is 6.5 - to 18 -year-olds.

\section{The right of indigenous children to learn their language at school according to international law}

This section examines the sources of international law that create the framework for the right of indigenous children to learn their native language at school. The core elements of the right of indigenous children to learn their mother tongue at school (the core elements of the right in focus) will be identified on the basis of the analyzed sources.

\subsection{Sources of international law providing for the right in focus}

There are a number of sources of international law, both binding and nonbinding, that proclaim that the right in focus is a fundamental human right. Binding sources include the following: the CRC, ${ }^{22}$ the International Covenant on Civil and Political 


\section{E. A. Zmyvalova}

Rights (ICCPR), ${ }^{23}$ the UNESCO Convention against Discrimination in Education, ${ }^{24}$ the ILO Convention No. 169 Concerning Indigenous and Tribal Peoples in Independent Countries (ILO Convention No. 169), ${ }^{25}$ the European Charter for Regional Minority Languages, ${ }^{26}$ and the Framework Convention for the Protection of National Minorities. ${ }^{27}$ Nonbinding sources include the Declaration on the Rights of Persons Belonging to National or Ethnic, Religious and Linguistic Minorities ${ }^{28}$ and the United Nations Declaration on the Rights of Indigenous Peoples (UNDRIP). ${ }^{29}$

One of the main treaties that ensures the right of indigenous children to learn their native language is the CRC, in particular Article 28, which guarantees that State parties recognize the right of a child to education, Article 29, which provides for the main aims of the education, and Article 30, which states:

In those States in which ethnic, religious or linguistic minorities or persons of indigenous origin exist, a child belonging to such a minority or who is indigenous shall not be denied the right, in community with other members of his or her group, to enjoy his or her own culture, to profess and practice his or her own religion, or to use his or her own language. ${ }^{30}$

Article 30 of the CRC, with special reference to children, reiterates the provision of Article 27 of the ICCPR. ${ }^{31}$ Although Article 30 of the CRC does not explicitly provide for a child's right to education in his or her own language, the CRC Committee has stressed the importance of multilingual education in the realization of the right to education for children belonging to a minority or indigenous population. ${ }^{32}$ This concern is in line with Article 5 (1.c) of the UNESCO Convention against Discrimination in Education, which states:

It is essential to recognize the right of members of national minorities to carry on their own educational activities, including the maintenance of schools and, depending on the educational policy of each State, the use or the teaching of their own language... ${ }^{33}$

In the General Comment No. 11 (2009), the CRC Committee emphasizes that ILO Convention No. 169 "contains provisions which advance the rights of indigenous peoples and specifically highlights the rights of indigenous children in the area of education." 34 Article 28 (1) of the ILO Convention No. 169 provides as follows:

Children belonging to the peoples concerned shall, wherever practicable, be taught to read and write in their own indigenous language or in the language most commonly used by the group to which they belong. When this is not practicable, the competent authorities shall undertake consultations with these peoples with a view to the adoption of measures to achieve this objective.

Other international treaties that guarantee indigenous children's right to learn their mother tongue are the European Charter for Regional Minority Languages (Article 8) and the Framework Convention for the Protection of National Minorities (Article 14).

By signing and ratifying legally binding sources of international law, States express their will and intention to support and implement the ideas of these legal instruments in 
their national legislation. The situation is different with nonbinding sources. According to legal scholar Stephen Allen, ${ }^{36}$ through joining nonbinding instruments States express their political will to support the ideas of these instruments. Allen's argument illustrates the significance of nonbinding sources of law for the present analysis.

Of particular importance is the Declaration on the Rights of Persons Belonging to National or Ethnic, Religious and Linguistic Minorities. Its Article 4 (3) stipulates:

States should take appropriate measures so that, wherever possible, persons belonging to minorities may have adequate opportunities to learn their mother tongue or to have instruction in their mother tongue. ${ }^{37}$

Of no less importance is UNDRIP, which has played a decisive role for indigenous peoples all over the world across many spheres of life, including education. The role of UNDRIP was emphasized by the CRC Committee in General Comment No. 11 (2009). Article $14(2,3)$ of UNDRIP provides:

2. Indigenous individuals, particularly children, have the right to all levels and forms of education of the State without discrimination.

3. States shall, in conjunction with indigenous peoples, take effective measures, in order for indigenous individuals, particularly children, including those living outside their communities, to have access, when possible, to an education in their own culture and provided in their own language. ${ }^{38}$

\subsection{The core elements of the right of indigenous children to learn their mother tongue at school}

As follows from the previous subsection, the ICCPR guarantees the right of indigenous peoples, and the CRC the right of indigenous children, to use their language. These treaties are of a general character, providing the basis for more specific rights. The sphere of education is not mentioned in these international treaties. However, the CRC Committee points out that there is a clear connection between the use of a language by indigenous children and education. Therefore, the right to learn a language acquires a special significance in the context of these treaties. Legal treaties such as the UNESCO Convention against Discrimination in Education recognize the importance of teaching indigenous languages. However, while the convention acknowledges its importance, Article 5.1.iii does not identify indigenous language education as a State obligation.

The European Charter for Regional or Minority Languages not only guarantees the right of indigenous children to learn their language at school, but also obliges State Parties to ensure the realization of this right. That the State is obligated to realize the right is crucial, and for this reason this obligation is included in the list of core elements of the right in focus.

As the treaties analyzed above are more general in content, ILO Convention No. 169 's special focus on indigenous peoples' issues means that it plays a central role in the international legal framework. Alongside other rights, the convention is also dedicated to the right of indigenous children to learn their mother tongue. Moreover, in the context of this right the indigenous peoples' opinions with regard to the issues 


\section{E. A. Zmyvalova}

concerning them are taken into consideration in the convention and thus create an element of the right of indigenous children to learn their mother tongue.

The Declaration on the Rights of Persons Belonging to National or Ethnic, Religious and Linguistic Minorities provides for the insurance of the right in focus; however, UNDRIP not only guarantees this right, but also focuses on the nondiscrimination character of this right. Nondiscrimination is one of the core elements of the right in focus. Moreover, it is important that nondiscrimination apply at all levels and in all forms of education in a State. Aside from stressing the importance of nondiscrimination, UNDRIP underlines the necessity of ensuring that measures providing for the quality of education be effective. Efficiency becomes the core element of the right of indigenous children to learn their native language, because without effective realization the other core elements lose their importance.

The analysis of the sources of international law on the right in focus illustrates that all of them are interconnected and their framework creates a basis for distinguishing a range of core elements integral to this right. These elements are as follows:

1. The right of indigenous children to learn their native language at school must be guaranteed by the State.

2. The State should create the necessary basis for children to realize this right at all levels and in all forms of education.

3. Realization of this right must be carried out without discrimination.

4. This right must be realized in an effective way.

5. The establishment and realization of this right must be carried out in such a way so that the opinion of indigenous peoples is taken into consideration.

\section{Implementation of the right of indigenous children to learn their native language at school in Russia}

\subsection{Formal implementation of international treaties}

The CRC, ICCPR, and UNESCO Convention against Discrimination in Education and the Framework Convention for the Protection of National Minorities have all been signed and ratified by the RF. The European Charter for Regional Minority Languages has been signed but not ratified. ${ }^{39}$ ILO Convention No. 169 remains unratified. It is not possible to analyze the formal implementation of nonbinding sources of law. However, the RF's endorsement of these nonbinding sources also impacts the right of indigenous children to learn their mother tongue at school. The Declaration on the Rights of Persons Belonging to National or Ethnic, Religious and Linguistic Minorities is relevant because the RF is a member of the UN General Assembly and the declaration was adopted by the Assembly (without a vote).$^{40}$ Regarding UNDRIP, the $\mathrm{RF}$ participated in its discussion, but abstained from voting.

\subsection{Opinions of monitoring bodies}

The latest concluding observations on the Russian Federation's report on the implementation of the ICCPR by the Human Rights Committee, which is the 
monitoring body for the implementation of the ICCPR, were presented on 31.03.2015. ${ }^{41}$ Even though the committee does not analyze violations of Article 27, which concerns the teaching of indigenous languages to indigenous children at school, it does comment on general problems in the Russian legal system that impact the appropriate implementation of the right in focus. Among the mentioned problems are violations of international law by Russia (para. 6), violations of human rights within the State (para. 7), and the absence of an independent judiciary (para. 17). It is worth mentioning that in para. 5 of the concluding observations, the committee "regrets the lack of clear information regarding the existence of efficient mechanisms and legal procedures for ensuring the full implementation of the Committee's Views and their operation in practice," ${ }^{42}$ reiterating para. 4 of its concluding observations of 24.11.2009. ${ }^{43}$ This paragraph pointed out that the greater part of the core recommendations from the previous periodic report of the Committee of $2003 \mathrm{had}$ not been implemented either. Additionally, in para. 8 of the concluding observations of $06.11 .2003^{44}$ the committee points to the systematic failure of the RF to implement the committee's views.

In the latest concluding observations, the committee "remains concerned (CCPR/ $\mathrm{C} / \mathrm{RUS} / \mathrm{CO} / 6$, para. 29) at insufficient measures being taken to respect and protect the rights of indigenous peoples and to ensure that members of such peoples are recognized as such." 45 In para. 29 of the concluding observations of 2009 the committee expressed its concern about the exclusion of Article 4 from the FL, "On Guarantees of the Rights of the Indigenous Small-Numbered Peoples of the Russian Federation." Before being excluded Article 4 stipulated that the state authority bodies of the RF, the state authority bodies of the subjects (constituent entities) of the RF, and the municipal authority bodies would ensure the rights of indigenous small-numbered peoples to independent socioeconomic and cultural development. Amendments were introduced into legislation due to a general policy aimed at financial compensation for social benefits. This policy led to the removal of some legal provisions on social guarantees from legislation, including Article 4 from the FL, "On Guarantees of the Rights of the Indigenous Small-Numbered Peoples of the Russian Federation.” It can be assumed that these changes in the cultural and social welfare system have impacted the social guarantees of the indigenous small-numbered peoples of Russia. That these amendments are still in force proves disregard of the recommendations of the Human Rights Committee.

Therefore, although in its latest report the committee draws attention to a large number of challenges and problems in the implementation of the ICCPR in the RF, the fact that the committee reiterates a list of similar problems and challenges from report to report gives grounds for real concern. From the latest three concluding observations of the Human Rights Committee it can be deduced that the RF has systematically disregarded the committee's views.

The latest concluding observations of the CRC Committee, which monitors the implementation of the CRC, on the combined fourth and fifth reports of the Russian Federation are dated $25.02 .2014 .^{46}$ In para. 9 the committee observes that the RF has to amend legislation concerning nondiscrimination in order to make it consistent 


\section{E. A. Zmyvalova}

with CRC provisions. Additionally, in the same paragraph the committee states that the Russian laws that already conform to the CRC must be fully and effectively implemented because this implementation is lacking in practice.

The committee also points out that there is no understanding of CRC provisions in Russia and that it considers this lack of understanding to be one of the reasons for the implementation problem. Thus, in para. $7 \mathrm{~b}$, the CRC Committee states that the $\mathrm{RF}$ needs to "establish a comprehensive policy with a view of strengthening efforts to ensure that the provisions of the Convention are widely known and understood by adults and children alike."

The committee is especially concerned about discrimination against children. According to para. 63, the Committee is "deeply concerned that, according to reports, the native languages of some indigenous groups are never used as a language of instruction in schools and are reduced to the status of minor subjects." ${ }^{\text {"47 }}$ In para. 64 the committee recommends that the RF "take all necessary measures to preserve the cultural and linguistic identity and heritage of indigenous children by ensuring that they receive basic education also in their native language to the extent it is possible." 48

To summarize, the committee draws attention to the problems of implementation of the international provisions into national legislation. Moreover, the committee points to the ineffectiveness of Russian laws containing nondiscrimination provisions.

The latest opinion of the monitoring body on the Framework Convention for the Protection of National Minorities, called Advisory Committee on the Framework Convention for the Protection of National Minorities (Advisory Committee), was announced on $24.11 .2011 .^{49}$ In para. 22 of the document, the Advisory Committee states that "the overall climate is not conducive to the use of minority languages in daily life" in the RF.

Furthermore, the Advisory Committee points out (para. 24) that

the right to take the state examination in a minority language was removed in 2009 . Federal legislative provisions concerning minority language education are too broad and often not effectively implemented at local level and there are no guarantees regarding weekly hours of minority language classes or quality standards of curriculum. ${ }^{50}$

The Advisory Committee states that it "regrets that opportunities to be taught in minority languages seem to be dismissed at the number of schools providing education in and of minority languages." ${ }^{51}$ Thus, the committee addresses the problem of tuition in the minority language.

When monitoring the two documents mentioned above, the committee found that general problems of implementation directly impact the realization of the right in question. The Advisory Commitee of the Framework Convention for the Protection of National Minorities draws attention to the problem of indigenous children in learning their mother tongue at school.

The Committee on Conventions and Recommendations in Education, which monitors the implementation of the UNESCO Convention against Discrimination in Education, does not submit an official report to each State. Instead it consults with member States. Nevertheless, the results of the latest consultations, published in 
$2013,{ }^{52}$ will be analyzed. Even though the RF is not mentioned in this document, the general tendencies pointed out by the committee are relevant to the present evaluation.

In Point 2 of the report, the committee points out that even though member States have constitutional and legislative frameworks of implementation for the Convention "it is equally important that policies are in place to ensure that principles (of the Convention, first of all nondiscrimination) are materialized." The principle has to be recognized and member States "have the duty to prohibit any form of discrimination in education and to promote equality of opportunity and treatment for all in education."

To conclude, the RF formally implemented a significant number of international treaties concerning the protection of the right of indigenous peoples to learn their native languages. However, the monitoring committees of these international treaties regularly point to the RF's systematic disregard for their conclusions on the implementation of the international treaties in practice. Despite the fact that the monitoring bodies point to other negative factors besides the RF's persistent avoidance of implementation, in the context of this article the focus is precisely on the causes of this problem.

\subsection{Discussion}

It is worth mentioning that problems concerning implementation of international treaties in general and those concerning indigenous peoples' rights in particular is a complex issue in Russia. I present a hypothesis arguing that the problems are exacerbated by peculiarities of the Russian realities.

Inevitably, the question of power must be raised. Regardless of the fact that the principle of rule of law $^{53}$ has been declared central to the RF, power lies with the president (the so-called power of the federal center). Scholars argue that the current Russian president has introduced a centralized, authoritarian leadership approach often referred to as superpresidentialism. ${ }^{54}$ Bobrova states that superpresidentialism creates conditions that "make authorities imitate the principles of democracy and people's power" 55 in Russia. Ebzeev comments that "the Russian president has a wide scope of powers and can act at his own discretion, independently from the Government and, moreover, he can fully control it." 56 The absence of the working principle of the Rule of Law, a "democratic deficit," 57 and the growth of politically powerful individuals in Russia have become typical. In recent years, these tendencies have become stronger and even more commonplace. This situation has led to the recognition that legislation is "purely 'decorative' in fact." 58

Another observation regarding the current political situation in Russia concerns Russia's autonomous status in international affairs, evident in many spheres, such as trade relations, military capabilities, and also indigenous peoples' affairs. Russian politicians often proclaim that Russia follows its own "special path" of development, which differs from that of the international community. According to sociological research, more and more Russians believe in this special path. ${ }^{59}$

The question of power has often been raised in connection to indigenous peoples' rights. In this sphere in particular the power creates "ill-judged and illegal" 60 


\section{E. A. Zmyvalova}

decisions. A vivid example of such a policy is the Russian Association of indigenous small-numbered peoples of the North, Siberia, and the Far East (RAIPON) - "the umbrella organization which represents more than 40 indigenous groups in the Russian Arctic and Far East." ${ }^{\text {"1 }}$ In 2012 the Ministry of Justice of the RF ordered this organization to close for six months. After RAIPON's status was reinstated, its former leader and "indigenous peoples rights activist Pavel Sulyandziga had to withdraw his candidate after pressure as Moscow and gas-hungry Yamal-Nenets Autonomous District urged the candidature of State Duma deputy from United Russia Georgy Ledkov." 62 Alexandra Artieva, a member of the Sami Parliament of the Kola Peninsula, has stated that authorities try to have minimal real cooperation with indigenous peoples in any circumstance. ${ }^{63}$

Currently the situation in Russia can be characterized as "imitating legal intentions to regulate indigenous relations." ${ }^{64}$ Indigenous peoples' rights are not assured and the State has not taken upon itself further obligations to guarantee the rights of indigenous small-numbered peoples. There are two main reasons for this situation. The first reason is that indigenous small-numbered peoples inhabit the territories where natural resources are exploited. As emphasized by Kharyuchi, "in those spheres where the principles of minorities benefit, minimal expenditure and maximum income prevail, other principles are of purely declarative character or are absent.." ${ }^{.65}$ This quotation refers to the principles of the international law, too. Proceeding with this idea, Kharyuchi explains the fact that current federal legislation in the field of development of the rights of indigenous small-numbered peoples must go hand in hand with international principles, but the latter "has stagnated for several years already." issue of the federal center's interest in the territories where resources are located is confirmed by the observation of the first vice-president of RAIPON, Rodion Sulyandziga, who highlights that "[t]here is an extensive hike in the level of industrialization in the north, and the indigenous peoples are among the last barriers against the companies' and states' development of the resources." 67

The second reason is the unwillingness to endow the indigenous small-numbered peoples of Russia with the right to self-determination in compliance with UNDRIP. Russia's position about joining UNDRIP was revealed by the minister of foreign affairs of the RF, Lavrov, in his response to the letter of the head of RAIPON, Kharyuchi, on 05.06.2006:

The project of the declaration contradicts the Russian legislation which does not provide for the right of indigenous peoples to land, mineral resources, natural resources and the right for self-determination in the forms supported by the international society. ${ }^{68}$

International human rights bodies, for example the Committee of Ministers of the Council of Europe, state in several documents that Russia has not complied with the requirements of international law. ${ }^{69}$ For instance, Russia did not follow the decisions of the European Court of Human Rights (ECHR), ${ }^{70}$ which are obligatory for Russia according to the FL of 30.03.1998, No. 54-FL, "On Ratification of the Convention for the Protection of Human Rights and Fundamental Freedoms and Its Protocols." ${ }^{\text {71 }}$ 
Moreover, according to the resolution of the Constitutional Court of the RF of 14.07.2015, the RF Constitution has priority over decisions of the ECHR. In cases where the Constitutional Court of the RF finds a decision of the ECHR contradictory to the provisions of the Constitution the former is not enforceable in Russia. ${ }^{72}$

In addition to the issues raised above, another problem is that Russia has repeatedly expressed its intentions to improve the situation within the country during negotiations with the international community, but in practice these intentions have not been realized. ${ }^{73}$ Despite Russian calls for international cooperation in the sphere of indigenous peoples' rights, its strong federal center creates challenges for such cooperation. For example, in 2014, one of the representatives of the Kola Sami from Russia, Valentina Sovkina, was obstructed by Russian authorities as she was leaving Russia to participate in the UN World Conference of Indigenous Peoples in New York. ${ }^{74}$

Negative tendencies towards the indigenous peoples of Russia also affect the safeguarding of indigenous languages. For example, while the Russian authorities have repeatedly declared that it is necessary to safeguard indigenous languages, priority is always given to the Russian language. ${ }^{75}$ Naturally, under these circumstances, despite declarations about the necessity to protect languages, in fact, the languages of indigenous small-numbered peoples of Russia are suffering.

To conclude, today the power of the strong federal center prevails in all spheres of life in Russia. In fact, the principle of the rule of law does not work. Therefore, there has been no appropriate implementation of the relevant international treaties that create a necessary legal framework for the right of indigenous children to learn their language at school in Russia. However, it is noteworthy that if the core elements of the right in question exist at the national level and this right is effectively realized, the goal may be achieved. Thus, the next section will examine whether this option exists in Russia.

\section{Realization of the right of indigenous children to learn their language at school}

This section first explores sources of Russian law that guarantee the right of children of indigenous small-numbered peoples to learn their native language and analyzes whether these sources contain the core elements of this right. Second, the Federal State Educational Standards ${ }^{76}$ for primary and secondary level education, which determine expected learning outcomes, including those regarding native language learning, are analyzed. This analysis will help to explain which outcomes children should get as a result of learning their native language at school. Last, the results of the interviews will be used to assess received learning outcomes and their compliance with the requirements of the Federal State Educational Standards. Since the analysis concerns the territory of the NAO, it should be kept in mind that the results in this section are fully applicable only to the Nenets people inhabiting this territory. However, certain conclusions may be typical of, or otherwise useful to, Nenets in other regions of Russia and other indigenous small-numbered peoples in Russia. 


\section{E. A. Zmyvalova}

\subsection{Legal sources of the Russian Federation}

The following federal laws guarantee, among other rights, the right of indigenous children to learn their mother tongue at school: FL "On Education," FL "On Guarantees of the Rights of Indigenous Small-Numbered Peoples of the Russian Federation," "77 FL "On Basic Guarantees of the Rights of the Child in the Russian Federation," ${ }^{78}$ FL "On the Languages of the Peoples of the Russian Federation,"79 and FL "On National-Cultural Autonomy.",

Acts passed by the federal bodies explicate, specify, and clarify the provisions of the federal legislation. The following acts of federal bodies contain provisions on the right of indigenous children to learn their native language: the Order of the Ministry of Education of the Russian Federation of 09.03.2004, No. 1312, "On the Approval of the Federal Basic Curriculum and the Preliminary Curricula for Educational Institutions in the Russian Federation, Implementing Programs for General Education"; 81 the Order of the Ministry of Education of the Russian Federation of 05.03.2004, No. 1089, "On the Approval of the Federal Component of the State Educational Standards of Primary General, Basic and Secondary (Complete) General Education." 82

Provisions of regional legislation cannot contradict any of above-mentioned provisions of federal legislation. However, since the sphere of education lies within the joint jurisdiction of the RF and the subjects (Article $72[1, \mathrm{e}]$ ), the latter can regulate those education policy questions that are not managed at the federal level. Thus, at the regional level of the NAO, the following sources guarantee the right in focus: the Charter of the NAO, ${ }^{83}$ the NAO law "On Education in the Nenets Autonomous Okrug," 84 and the NAO Law "On the Nenets language in the Nenets Autonomous Okrug." 85

All of the foregoing sources as well as the Constitution of the RF create the necessary basis for the Nenets children learning their native language at NAO schools. The Constitution of the RF contains first two core elements of the right of indigenous children to learn their language, justified by the content of Article 26 (2), which ensures the right to the free choice of education, and Article 68 (3), which states that "The Russian Federation shall guarantee to all of its peoples the right to preserve their native language and to create conditions for its study and development." ${ }^{86}$ The third criterion, focusing on nondiscrimination, is guaranteed by Article $3(1,2)$ of the FL "On Education," which states that state policy on education must be based on the principle of nondiscrimination. The criterion that there must be a legal provision on the realization of the right in an effective way is contained in Russian legislation as well. Since the legislator can predict the completion of certain learning outcomes as a result of the learning process (enumerated in Subsection 5.2), the establishment of learning outcomes can be viewed as fulfillment of the criterion for achieving the effective realization of this right. The criterion that the establishment and realization of this right must be carried out with consideration of the opinion of the indigenous peoples is partly addressed in the federal legislation (for example, Article $5[1,2]$ of the FL "On Guarantees of the Rights of Indigenous Small-Numbered Peoples of the Russian 
Federation") and explicitly addressed in regional legislation, which includes the NAO legislation as well.

\subsection{Position of legislature}

Legislation on learning outcomes for the subject of native language ${ }^{87}$ can be found in the Order of the Ministry of Education and Science of 06.10.2009, No. 373, "On the Approval and Introduction into Force of the Federal State Educational Standard of Primary General Education" and the Order of the Ministry of Education and Science of 17.12.2010, No. 1897, "On the Approval of the Federal Educational Standard of the Basic General Education."

Since the Nenets language is taught within the subject "Native (non-Russian) language and literature" in the Indiga school, the provisions of these orders are applicable to this subject and correspondingly in schools where children learn the subject. In Krasnoye, the Nenets language is also taught in school, though in two other subjects. Therefore, the learning outcomes established in the legislation can be regarded as applicable to the children in Krasnoye for further analysis.

As a result of the analysis of the provisions of these two documents concerning native language as a school subject, certain learning outcomes can be enumerated. These outcomes are as follows:

The child must

1. Have competencies in comprehending, reading, speaking, and writing the native language

2. Be able to create linguistic discourse (sentences, texts, etc.)

3. Have a conceptual understanding of the language

4. Have the necessary vocabulary to express his or her thoughts and feelings adequately

5. Have a command of the stylistic and phraseological resources of the language

This list of learning outcomes is used as a basis for the assessment of the effectiveness of the realization of the right of indigenous small-numbered peoples to learn their mother tongue. If a child is capable of achieving these learning outcomes, it can be concluded that the right has been effectively realized; if not, it is only a formal right. Whether or what problems exist will be clarified by an analysis of the interviews and the collected data below.

\subsection{Results of the interviews}

At both schools, the principals, vice-principals in charge of the school curricula, and teachers of the Nenets language were interviewed. Furthermore, interviews with four parents in Indiga and three parents in Krasnoye were conducted.

The interviews helped to determine which learning outcomes provided by law were fulfilled by pupils and to draw conclusions about the effectiveness of the realization of the right in focus. Furthermore, the opinions of the interviewees on the causes for gaps in realization were also analyzed. 


\section{E. A. Zmyvalova}

In both schools all of the parents rated their children's competence in the Nenets language as limited or weak. All parents interviewed confirmed that their children were not able to communicate in the Nenets language and the only thing they could do was practice translation using a Nenets-Russian dictionary. For example, one of the parents in Indiga who rated the knowledge of her child in the Nenets language as limited said that "he can translate some things, but if one says something in the Nenets language for sure he will not understand anything." 88 Another parent from Krasnoye stated that his daughter "learns poems in the Nenets language by heart but after class she forgets everything and that's it." 89

The teachers also expressed their opinions regarding children's competence in the Nenets language. The teacher of the Nenets language from Krasnoye explained that "nowadays all school children including tundra children speak Russian. They do not know the Nenets language." 90 The Nenets language teacher from Indiga corroborated, saying, "School children do not know the language, but they can translate texts using a dictionary without any problem." 91

Regarding questions about how to improve Nenets language teaching, answers differed. Parents in Indiga said that they want their children to have the opportunity to communicate orally in class, while in Krasnoye parents either chose not to answer the question, or said that their children did not need to learn the Nenets language at all. This response is related to the fact that in the village of Krasnoye, parents had already succeeded with their demand to drop "Native (non-Russian) language and literature" as a school subject because, from their point of view, there was no need for children to learn the Nenets language.

The vice-principal of the school in Krasnoye confirmed that the school subject "Native (non-Russian) language and literature" had been dropped, causing the school week to shorten from six to five days in length. She commented that if the Nenets language were added to the school curriculum as a separate subject it would require an increase in teaching hours and correspondingly lead to a longer school week of up to six days. She added that, although the school administration is responsible for making decisions regarding Nenets language classes, the influence of the parents was so strong that the school had to change the curriculum. The main arguments of the parents were that pupils' workloads were too heavy and that children would ultimately take their exams in Russian, not in the Nenets language. She explained that even if pupils learned the Nenets language they would not need it in life, and that, therefore, there was no motivation to learn the Nenets language.

Thus, the teachers and parents confirmed the absence of competence in the Nenets language envisaged by the legislation, while they also expressed their opinions about why pupils were lacking in terms of knowledge of the Nenets language.

The interviews also illustrated that frequent changes in legislation hinder the consequential educational process. The principal of the Indiga school said, "We live in the time of changes. We have to accept that everything is changing fast. It is true that we got used to the changes which leads to a lot of questions." ${ }^{2}$ Teachers also confirmed that frequent changes in legislation create a situation in which there is no 
order or structure in the teaching of the Nenets language as far as regulations are concerned.

Another issue respondents raised was that of the absence of the learning environment. ${ }^{93}$ The Nenets language teacher from Krasnoye explained, "We are made to teach the Nenets language in 1 hour per week. I cannot jump over my head. ${ }^{94}$ Moreover, parents do not speak the language at home."95

The Nenets language teacher from Indiga commented, "At home children do not repeat what they have learned at school. There is no environment. Even if somebody in class has potential, they do not even try to speak because the majority do not speak the language." 96

Another factor that impacts the learning environment was emphasized by the Nenets language teacher from Indiga. She raised an issue about textbooks, as the textbooks used in NAO schools are issued in the YNAO, even though the language competencies of children from these two regions vary considerably, with the level in the YNAO being higher than in the NAO. Because of this difference in competencies, the use of YNAO textbooks in the NAO is questionable.

\subsection{Discussion}

According to the results of interviews, indigenous children's right to learn their native language at school is not being realized in the NAO. Children do not achieve the learning outcomes that they are supposed to meet after learning the Nenets language. There are a variety of reasons for these gaps in realization, which are partly connected to problems of implementation of the international treaties on indigenous children's right to learn their language. These problems can be subdivided into three groups. The first group of problems is connected to the frequent changes in the legislation. The second group can be attributed to the vague formulations of the legal provisions. Finally, the learning environment can also be seen as contributing to the lack of proper realization. This list of problems is not exhaustive, and alternative approaches can be suggested.

The interview respondents drew attention to the problem of the frequent changes in legislation, an opinion that prevails not only among practitioners, but also at the state level. Russian Prime Minister Medvedev explains that "the instability of the legal regulations, frequent changes of the legislation, internal discrepancies and controversies between legal acts, and low linguistic quality of the text are factors undermining the effectiveness of State management." 97

This opinion is widely discussed in Russian legal literature. For example, Kukushkin points out that "due to frequent changes of the legislation in the sphere of joint competence of the federation and the subjects of the federation, the legislative bodies do not have enough time to amend their normative acts; in the majority of the subjects the external scientific legal expertise is not carried out." 98

The problem of federalism contributes to the problem of frequent changes in legislation in the subjects of the federation, not to mention the fact that legislative changes made at the federal level are not followed up at the local level. A characteristic feature of the Russian federal system is that some of the subjects of the federation are 


\section{E. A. Zmyvalova}

designated according to the matryoshka principle. ${ }^{99}$ The Arkhangelsk Oblast and NAO belong to this group of federal subjects. Until 2014 the Arkhangelsk Oblast's jurisdiction included regulating educational issues in the NAO. In October 2014, the NAO acquired responsibility for the educational sphere and within a two-month period, as of $01.01 .2015^{100}$ changes were expected to be introduced in all regulatory acts. This illustrates the unrealistic nature of these changes.

The second factor is the low linguistic quality of the legal texts, pointed out by state authorities and legal scholars. Not only do Medvedev and Kukushkin draw attention to this problem, but so does Gladkikh, for example. He observes: "The vagueness of the legal norms typical of the Russian legislation creates difficulties in understanding the laws not only for common people, but also for learned legal experts." 101

The last, but not least, contributing factor that impacts the realization of the right of indigenous children to learn their language in the NAO is the issue of the learning environment, which has meant that indigenous children have not been able to appropriately learn their mother tongue. This group of problems can be defined as non-legal. However, their significance cannot be underestimated.

The factor with the greatest impact on the learning environment is that parents do not speak their indigenous language. The situation at home and in their communities, which are the "environments in which the language can be used on a regular basis," 102 leaves much to be desired.

Another factor impacting the learning environment is the gap between educational institutions (in the present case it is kindergartens and schools) where the Nenets language is taught. According to the 2014 Report of the NAO Administration ("Annual Report on the Realization of the State Policy in the Sphere of Education in the Nenets Autonomous Okrug"), there are 14 schools where the Nenets language is taught. There are seven kindergartens where the Nenets language is taught, and the level of linguistic preparedness among the first-year pupils varies greatly. The requirements and textbooks are the same for all pupils, but starting levels can be vastly different.

Textbooks present yet another problem. The frequent changes to the legislation somehow do not result in frequent changes in textbooks. Besides this issue, the textbooks used in NAO are issued in YNAO, where the Nenets language proficiency of pupils is greater.

Another factor impacting the learning environment is that legislators have not thoroughly envisaged conditions for language development. For example, pupils can only take final exams in Russian, which places more importance on learning the Russian language and does not motivate children to learn their native language.

Finally, the only way to teach the Nenets language at school presently is to provide children with additional hours, which lengthens the school week from five to six days. In the NAO schools where the Nenets language is taught as a separate subject "The Native [non-Russian] language and literature," children are at school six days per week. Thus, by providing indigenous small-numbered peoples with the special right to indigenous language education, the legislation in fact discourages the study of the 
Nenets language by increasing pupils' workloads, while having no formal exams in the Nenets language.

\section{Conclusion}

Based on the analysis of the sources of international law that ensure the right of indigenous children to learn their mother tongue at school, the core elements of this right were identified. The Russian legislation provides for these elements and specifies their application to Russian realities.

However, despite the fact that most of the international treaties in the sphere of regulation of this right have been implemented in Russia, it has become clear that formal implementation does not mean that implementation is carried out in fact. While the national legislation provides for the right, its realization is not confirmed by the results of the interviews. Thus, it can be concluded that neither effective implementation nor realization have materialized.

Problems of implementation in Russia are related to the current political situation, as it is not the rule of law, but rather the supremacy of presidential power that prevails in Russia today. The political will of the president is aimed at defining independent Russian development, separate from the international community: the so-called special path of Russian development. This causes Russia's noncompliance with commitments vis-à-vis the international community, inter alia indigenous children's right to learn their language.

There are also a number of other reasons for the ineffective realization of the right of indigenous children to learn their language at school. These reasons include the problem of frequent changes in legislation, the low linguistic quality of legal texts, and the absence of a learning environment.

\section{NOTES}

1. In the context of this article, mother tongue is the language that indigenous peoples are identified with, even if they may not have learned it first. This definition can also be used in combination with an external identification: the language that they are being identified with as native speakers by others. In this article the terms mother tongue, native language, and own language are used synonymously.

2. Concluding observations on the combined fourth and fifth periodic reports of the Russian Federation (CRC/C/RUS/CO/4-5).

3. Information Materials on the Final Results of the National Population Census 2010, Federal State Statistics Service, http://www.gks.ru/free_doc/new_site/perepis2010/perepis_ itogi1612.htm (accessed April 29, 2015).

4. The RF Government Resolution of 24.03.2000, No. 255, "On the Unified list of Indigenous Small-Numbered Peoples of the Russian Federation" reads that there 47 groups of indigenous small-numbered peoples live in Russia. The group of Nenets people is the biggest one. According to the last census of 2010 there are 44,640 Nenets people who live in the territories of the YNAO, the NAO, the Arkhangelsk Oblast, the Krasnoyarsk Krai, the Khanty-Mansi Autonomous Okrug, and the Komi Republic. The majority of the Nenets people inhabit the YNAO and the NAO. 


\section{E. A. Zmyvalova}

5. Russia is a federal state consisting of units with equal status, which are called the subjects of the federation. They have different designation (okrugs, krais, etc.).

6. The National Population Census 2002, Indigenous Small-Numbered Peoples of the Russian Federation, Federal State Statistics Service, http://www.perepis2002.ru/index. html?id=44 (accessed June 22, 2015).

7. See Andrei Zhuravskii, Sustainable Development of Indigenous Small-Numbered Peoples: The Russian Experience (Moscow: Ministry of Culture of the RF, 2015); and Gasheva Tat'yana, "On the Right to Choose the Native Language by the Indigenous Small-Numbered Children of the High North" Ombudsman for Children in NAO, http:/detinao.ru/rights/ tesis/?ELEMENT_ID=7261 (accessed June 19, 2015).

8. Vladimir Kryazhkov, "Development of Russian Legislation on Northern Indigenous Peoples," Arctic Review on Law and Politics vol. 4, no. 2 (2013): 149.

9. Sergei Kharyuchi, "Problems of Improving of the Russian Legislation in the Sphere of Indigenous Small-Numbered Peoples Rights," Constitutional and Municipal Law, no. 2 (2009): 16.

10. Liv Inger Somby, "Ny lov svekker urfolkssprak," [New law weakens indigenous language] NRK Sapmi, Last modified January 3, 2013, http://www.nrk.no/sapmi/ny-lov-svekkerurfolkssprak-1.10859792 (accessed June 10, 2015); and Thomas Nilsen, "New Law Discriminates Indigenous Languages," Barents Observer, Last modified January 3, 2013, http:// barentsobserver.com/en/society/2013/01/new-law-discriminates-indigenous-languages03-01 (accessed April 21, 2015).

11. General Comment No. 5 (2003), (CRC/GC/2003/5).

12. Monitoring the Core International Human Rights Treaties, United Nations Human Rights, http://www.ohchr.org/EN/HRBodies/Pages/TreatyBodies.aspx (accessed June 19, 2015).

13. Ibid.

14. Lyudmila Khomich, The Nenets (St. Petersburg: Russian Yard, 1995), 29.

15. Article 66 (4) of the Constitution of the Russian Federation provides an option whereby one subject of the RF is included into another subject of the RF. According to Article 4 (1) of the Charter of Arkhangelsk Oblast, this oblast includes the NAO.

16. Such an administrative-territorial unit existed from 1921 to 1977 and was characterized by the fact that a non-Russian population occupied it. National okrugs had administrative autonomy and were part of krais or oblasts.

17. Alexander Ignatiev, "The Nenets Autonomous Okrug," The Arctic Herald 1, no. 1 (2012): 94 .

18. Information materials on the final results of the National Population census 2010, Federal State Statistics Service, http://www.gks.ru/free_doc/new_site/perepis2010/perepis_itogi 1612.htm (accessed April 29, 2015).

19. Annual report on the implementation of the Nenets Autonomous Okrug of the state policy in the sphere of education, Administration of the Nenets Autonomous Okrug, 2014.

20. Municipality "Primor-Kui Local Council" of the Nenets Autonomous Okrug, Pksovet.ru, http://pksovet.ru/ (accessed April 28, 2015).

21. FL of 29.12.2012 No. 273-FL "On Education in the Russian Federation."

22. CRC (entry into force: 02.09.1990).

23. ICCPR (entry into force: 23.03.1976).

24. Convention against Discrimination in Education (entry into force: 22.05.1962).

25. ILO Convention No. 169 (entry into force: 05.09.1991).

26. European Charter for Regional and Minority Languages (entry into force: 01.03.1998).

27. Framework Convention for the Protection of National Minorities (entry into force 01.02.1998). 
28. Declaration on the Rights of Persons Belonging to National or Ethnic, Religious and Linguistic Minorities (adopted: 18.12.1992).

29. UNDRIP (adopted: 13.09.2007).

30. CRC (entry into force: 02.09.1990).

31. This connection was underlined by the CRC Committee in General Comment No. 11 (2009) where it stated: "The Committee recalls the close linkage between Article 30 of the CRC and Article 27 of the ICCPR." See General Comment No. 11 (2009), CRC/C/ $\mathrm{GC} / 11$.

32. See Mieke Verheyde, Commentary on the United Nations Convention on the Rights of the Child. Article 28 (Boston, MA: Martinus Nijhoff, 2006), 42.

33. Convention against Discrimination in Education (entry into force: 22.05.1962).

34. General Comment No. 11 (2009), CRC/C/GC/11.

35. ILO Convention No. 169 (entry into force 05.09.1991).

36. Stephen Allen, "The UN Declaration on the rights of indigenous peoples and the limits of the international legal project," in Reflections on the UN Declaration of the rights of indigenous peoples, ed. Stephen Allen and Alexandra Xanthaki (Oxford: Hart Publishing, 2011), 225-56.

37. Declaration on the Rights of Persons Belonging to National or Ethnic, Religious and Linguistic Minorities (adopted 18.12.1992).

38. UNDRIP (adopted 13.09.2007).

39. Signing of international treaty does not necessarily lead to creation of the commitments of the RF. Ratification in the form of a national legal act creates Russia's international obligations (See Article 14 FL of 15.07.1995 No. 101-FL. "About International Treaties of the Russian Federation”). European Charter for Regional Minority Languages does not have legal force in the RF.

40. Rights of Persons Belonging to National or Ethnic, Religious and Linguistic Minorities, the UN Refugee Agency, Last modified May 8, 2015, http://www.refworld.org/docid/ 3b00f0d24a.html (accessed May 10, 2015).

41. Concluding observations of the Human Rights Committee. Russian Federation. (CCPR/C/ RUS/CO/7).

42. Ibid.

43. Concluding observations of the Human Rights Committee. Russian Federation (CCPR/C/ $\mathrm{RUS} / \mathrm{CO} / 6)$.

44. Concluding observations of the Human Rights Committee. Russian Federation (CCPR/ CO/79/RUS).

45. Concluding observations of the Human Rights Committee. Russian Federation (CCPR/C/ $\mathrm{RUS} / \mathrm{CO} / 7$ ).

46. Concluding observations on the combined fourth and fifth periodic reports of the Russian Federation (CRC/C/RUS/CO/4-5).

47. Ibid.

48. Ibid.

49. Third Opinion on the Russian Federation, adopted on 24.11.2011 (ACFC/OP/ $\operatorname{III}(2011) 010)$.

50. Ibid.

51. Ibid.

52. Implementation of the Convention and Recommendation against Discrimination in Education, UNESCO, http://unesdoc.unesco.org/images/0022/002221/222100E.pdf (accessed April 28, 2015).

53. See, for example, Article 15 (4) of the Constitution of the RF. Furthermore, prime minister of the RF Medvedev states, "[b]ut it seems equally important that new Constitution, 
adopted in an all-people referendum, for the first time in thousands of years of Russia's history declared Russia as a Rule of Law State. For the first time the Rule of Law and legal order have become ideological basis of the long-term development, the principles governing construction of the entire system of the social relations." See Dmitry Medvedev, "Constitution, Functions of the Government of Russia and Effective Management Technologies," Zakon, no. 12 (2013): 33.

54. Andreas Heinemann-Grüder, "Is Russia's Federalism Sustainable?," Perspectives on European Politics 3, no.1 (2011): 68.

55. Natal'ya Bobrova, "20 Years and 20 Drawbacks of the Constitution of Russia," Constitutional and Municipal Law, no. 3 (2013): 33.

56. Boris Ebzeev. "Article 1," in Commentary to the Constitution of the Russian Federation, ed. Viktor Zor'kin (Moscow: Norma, 2011), 49-65.

57. Heinemann-Grüder, "Is Russia’s Federalism Sustainable?," 69.

58. Kryazhkov, "Development of Russian Legislation," 50.

59. See "More than Half of Russians Prefer 'Special Path' of the Russian Federation - Survey," Cenzor.Net, http://censor.net.ua/news/333546/bolee_poloviny_rossiyan_predpochitayut_ osobyyi_put_razvitiya_rf_opros (accessed May 6, 2015).

60. These words were used by the first vice president of RAIPON, Rodion Sulyaudziga, to describe the closing of RAIPON in 2012. See Atle Staalesen, "Hard-Fought New Life for RAIPON," Barents Observer, Last modified March 15, 2013, http://barentsobserver.com/ en/society/2013/03/hard-fought-new-life-raipon-15-03 (accessed April 28, 2015); and Atle Staalesen, "RAIPON Fights for Survival," Barents Observer, Last modified November 19, 2012, http://barentsobserver.com/en/arctic/raipon-fights-survival-19-11 (accessed April 28, 2015).

61. Staalesen, "Hard-Fought New Life for RAIPON."

62. Thomas Nilsen, "Dmitry Berezhkov Arrested by Norwegian Police," Barents Observer, http://barentsobserver.com/en/politics/2013/06/dmitry-berezhkov-arrested-norwegian-police14-06 (accessed April 28, 2015).

63. Alexandra Artieva, "Sami Parliament of Kola Peninsula: Fight for Right to SelfDetermination," Barents Observer, http://barentsobserver.com/en/opinion/2014/11/samiparliament-kola-peninsula-fight-right-self-determination-20-11 (accessed April 28, 2015).

64. Kryazhkov, "Development of Russian Legislation," 51.

65. Sergei Kharyuchi, "Present Status and Ways of Development of Indigenous Peoples in the North, Siberia and Far East of the Russian Federation," in Current Status and Ways of Development of Indigenous Small-Numbered Peoples of the North, Siberia and Far East, ed. Vyacheslav Shtuirov (Moscow: Federal Council of the Federal Assembly of the Russian Federation, 2012), 37.

66. Ibid., 38.

67. Staalesen, "Hard-Fought New Life for RAIPON."

68. See Ruslan Garipov, "The UN Declaration on the Rights of Indigenous Peoples and the Legislation of the Russian Federation," in Current Status and Ways of Development of Indigenous Small-Numbered Peoples of the North, Siberia and Far East, ed. Viacheslav Shtyrov (Moscow: Federal Council of the Federal Assembly of the Russian Federation, 2012), 322.

69. The Committee of Ministers of the Council of Europe can state that Russia does not comply with the decisions of the ECHR. See "Cases against the Russian Federation," Council of Europe, https://wcd.coe.int/ViewDoc.jsp?id=2297877\&Site=COE\&BackColor Internet $=$ C3C $3 \mathrm{C} 3 \&$ BackColorIntranet $=$ EDB021\&BackColorLogged $=$ F5D383 (accessed April 30, 2015); see also Interim Resolution CM/ResDH(2015) 45 of the Council of Europe and Interim Resolution CM/ResDH(2015)46 of the Council of Europe. 


\section{Indigenous children's right to learn their mother tongue in Russia}

70. "ECHR Ruling on Compensation to Yukos Shareholders Unfounded, Russia Unlikely to Comply-Justice Minister (Part 2)," Interfax, http://www.interfax.com/newsinf.asp? $\mathrm{id}=599018$ (accessed July 14, 2015).

71. FL of 30.03.1998 No. 54-FL "On Ratification of the Convention for the Protection of Human Rights and Fundamental Freedoms and Its Protocols."

72. "On 14.07.2015 the Constitutional Court of the RF Proclaimed the Resolution on Applicability of the ECHR Decisions on the RF's Territory." Constitutional Court of the Russian Federation, http://www.ksrf.ru/ru/News/Pages/ViewItem.aspx?ParamId=3244 (accessed July 14, 2015).

73. Kryazhkov, "Development of Russian Legislation," 52.

74. Thomas Nilsen, "Alarming Situation for Indigenous Peoples in Russia," Barents Observer, Last modified September 23, 2014, http://barentsobserver.com/en/politics/2014/09/alarmingsituation-indigenous-peoples-russia-23-09 (accessed April 29, 2015); Thomas Nilsen, "Sami Leader Harassed by Police on Her Way to UN Conference," Barents Observer, Last modified September 22, 2014, http://barentsobserver.com/en/politics/2014/09/samileader-harassed-police-her-way-un-conferance-22-09 (accessed April 29, 2015); and Thomas Nilsen, "Russia to Give Indigenous Peoples Priority in Barents Chairmanship," Barents Observer, Last modified February 5, 2015, http://barentsobserver.com/en/politics/ 2015/02/russia-give-indigenous-peoples-priority-barents-chairmanship-05-02 (accessed April 29, 2015).

75. See Sergei Kanashevich, "Medinskii Called to Sacrifice Regional Languages for Russian," $R B K$, Last modified July 3, 2014, http://top.rbc.ru/society/03/07/2014/934389.shtml (accessed May 9, 2015); and Il'ya Massukh, "The Ministry of Communications of the Russian Federation Saw the Threat of the Use of the Languages of Peoples of Russia in the Internet," Last modified September 15, 2011, finugor.ru, http://finugor.ru/node/21203 (accessed May 9, 2015).

76. The Federal State Educational Standard is a set of mandatory requirements for the achievement of a certain level in a profession, specialty, or field of study, approved by the federal executive authority performing the functions of formulation of public policy and legal regulation in the sphere of education. See Article 2 of FL "On Education."

77. FL of 30.04.1999 No. 82-FL "On Guarantees of the Rights of Indigenous SmallNumbered Peoples of the Russian Federation."

78. FL of 24.07.1998 No. 124-FL "On Basic Guarantees of the Rights of the Child in the Russian Federation."

79. FL of 25.10.1991 No. 1807-1 "On the Languages of the Peoples of the Russian Federation."

80. FL of 17.06.1996 No. 74-FL "On National-Cultural Autonomy."

81. Order of the Ministry of Education of 09.03.2004 No. 1312 "On the Approval of the Federal Basic Curriculum and the Preliminary Curricula for Educational Institutions in the Russian Federation, implementing programs for general education."

82. Order of the Ministry of Education of 05.03.2004 No. 1089 "On the Approval of the Federal Component of the State Educational Standards of Primary General, Basic and Secondary (complete) General Education."

83. Charter of the Nenets Autonomous Okrug of 11.09.1995.

84. NAO Law of 16.04.2014 No. 12-OL "On education in the Nenets Autonomous Okrug."

85. NAO Law of 18.03.2013 No. 4-OL "On the Nenets language in the Nenets Autonomous Okrug."

86. The Constitution of the Russian Federation (1993).

87. The orders of the Ministry of Education and Science of the RF of 06.10.2009, No. 373, "On the Approval and Introduction into Force of the Federal State Educational Standard of Primary General Education" and of 17.12.2010, No. 1897, "On the Approval of the Federal Educational Standard of the Basic General Education," focus on native language as 


\section{E. A. Zmyvalova}

a school subject. However, the author has come to the conclusion that the requirements for the subject of native language are applicable to the subject "Native (non-Russian) language and literature" mentioned in the order of the Ministry of Education and Science of 09.03.2004, No. 1312. Even though the terms in these orders are different, they are applicable to the same school subject.

88. Interview of August 25, 2014 (Indiga, NAO).

89. Interview of September 2, 2014 (Krasnoye, NAO).

90. Interview of September 1, 2014 (Krasnoye, NAO).

91. Interview of September 4, 2014 (Naryan-Mar, NAO).

92. Interview of August 28, 2014 (Indiga, NAO).

93. By learning environment the author means the scope of different factors impacting the learning process (whether parents speak the native language, whether there is transition between schools and kindergartens where indigenous children learn their mother tongue, etc.).

94. One cannot do what is beyond his abilities. See Выше головы не прыгнешь [One Cannot Jump Over the Head], academic.ru, http://proverbs_ru_en.academic.ru/1960/\%D0\%92\% D1\%8B \%D1\%88\%D0\%B5_\%D0\%B3\%D0\%BE\%D0\%BB\%D0\%BE\%D0\%B2\%D1\% 8B_\%D0\%BD\%D0\%B5_\%D0\%BF\%D1\%80\%D1\%8B\%D0\%B3\%D0\%BD\%D0\%B5\% D1\%88\%D1\%8C (accessed May 9, 2015).

95. Interview of September 1, 2014 (Krasnoye, NAO).

96. Interview of September 4, 2014 (Naryan-Mar, NAO).

97. Medvedev "Constitution, Functions of the Government of Russia," 33.

98. Mikhail Kukushkin, "On the Question of Expert Evaluation of Draft Laws in the Russian Federation," Russian Legal fournal, no. 6 (2012): 202-3.

99. This expression means that they have a complex structure. One federal subject includes another.

100. See Regional Law of 24.10.2014, No. 188-11-OL “On amendments to some regional laws, suspension of certain regional laws and regulations of certain regional laws and invalidation of certain regional laws and regulations of certain regional laws in connection with the conclusion of the agreement between the bodies of state power of Arkhangelsk Oblast and Nenets Autonomous Okrug on cooperation when performing the functions of the public authorities of subjects of the Russian Federation."

101. Sergei Gladkikh, "On Declarative Nature of Social Rights," Legislation and Economics, no 12, (2013): 56.

102. Leorene A. Grenoble and Lindasy J. Whaley, Saving Languages: An Introduction to Language Revitalization (Cambridge: Cambridge University Press, 2006), 1. 